\title{
Re-use of historic wooden verandas in Sopot, Poland
}

\author{
J. Poplatek \& J. Bąkowski \\ Faculty of Architecture, Gdansk University of Technology, Poland
}

\begin{abstract}
Sopot is the best-known seaside resort in Poland. The city is unique with regard not only to its location and natural values, but also its interesting architecture, which dates back to the end of the 19th and the beginning of the 20th century. Wooden verandas are one of the characteristic features of Sopot architecture. Their origin is associated with the Swiss style, which was fashionable at the turn of the 20th century and quite common in numerous European resorts of the day. Verandas were used as summer parlours, where the guests could eat their meals and protect themselves from the caprices of summer weather. After World War II the majority of private lodging houses, tenement houses and residences became municipal property. During the following decades the technical condition of the houses, with no owners to ensure their proper maintenance, steadily deteriorated. This was the situation until the beginning of the 1990s, when Poland regained its sovereignty and became a fully democratic country. Revitalisation activities aimed at revival of the former splendour and cultural value of historic houses in Sopot were launched. This paper defines the basic types of historic verandas and their characteristic features, as well as the ways in which they were placed on the façades, depending on the form of the building. The main part of the article describes the possibilities of modernizing verandas and adjusting them to user requirements currently applied to living areas. It also refers to the issues of construction, thermal protection, fire protection and energy saving in the context of sustainable development.
\end{abstract}

Keywords: historic wooden structures, historic building modernization. 


\section{Introduction}

The seaside resort of Sopot is one of the best recognized cities in Poland. Its popularity may be attributed to the unique combination of landscape, natural values and historic architecture.

The city is located on the Baltic Sea (the Bay of Gdańsk) on two terraces connected by a 20 meter high slope (so-called "dead cliff").From the west, the city is surrounded by forests, which constitute almost a half of its area. All this means that the climate conditions in the city are excellent. The dynamic development of Sopot began in the 19th century, when it changed from a small fishing village into a spa, and at the beginning of the 20th century it received city rights. At that time, the Spa House, the Forest Opera, the horse racetrack, the balneological centre, the pier and many guest houses and hotels were built. Sopot was a place vibrating with life.

The relic of that era is the largest in the country number of buildings characteristic for the Northern European seaside resorts. The architecture of historical Sopot is dominated by eclectic influences, including mainly the features of Neo-gothic, Art-Nouveau and even early modernism. Sopot architecture is distinguishable by its richness of form, including wooden verandas, turrets, bay windows and architectonic details. The unique image of Sopot, which is a mosaic of landscape values and architecture from the turn of the 20th century constitutes valuable cultural heritage and its preservation is extremely important [1]. This article is dedicated to wooden verandas, one of the most characteristic features of Sopot architecture.

\section{Sopot after World War II}

During World War II, the city did not suffer any major losses. Only 5\% of the existing buildings were damaged, which number does not carry any statistical significance. Residential districts of the city survived without any serious damage. However, the representative part of the city was destroyed, which was a great loss, even though it did not show as such in the statistics.

The period following the war, which lasted for almost 50 years, was not a very good time for Poland. That was a period of the country's dependence of its Soviet neighbour, the time of economic stagnation and isolation from the Western Europe and the free world. Those 50 years were not good for Sopot, either. The majority of private property was taken away from its legal owners. Requisition of private property was commonly used during post-war years and Sopot was no exception. The communist authorities "accommodated" new residents in the requisitioned residential buildings, randomly dividing large flats into smaller ones, or even into single rooms with common bathrooms or kitchens. Such practices made it possible to ease, temporarily, the problem of flat shortage, but had a catastrophic impact on the condition of the buildings during the following decades. The residents, not being co-owners of the property, left the obligation to maintain the buildings in good condition to the municipality which, due to the permanent economic crisis, was not able to perform the necessary works. Only short-term, fragmentary 
renovation works necessitated by various failures were conducted. As a result, the condition of the buildings deteriorated over the years.

Public utility facilities, which by the (communist) definition remained in the possession of the municipality, were in an equally bad situation. Their maintenance was as poor as in the case of tenement houses and villas. Moreover, long lasting disregard for architecture dating back to the turn of 19th and 20th century was another adverse factor which, in extreme cases, led to hasty decisions which resulted in demolishing historic buildings [2].

In 1989 Poland regained its sovereignty and became a fully democratic country. At last, the process of making up for long-standing negligence could begin. Residents of severely degraded multi-family houses were gradually becoming their owners, which gave them the causative power to restore proper quality of their houses and surroundings. Social awareness concerning the importance of caring not only for individual historic buildings, but also for the character and composition of the district and the city was slowly developing. Revitalisation activities aimed at revival of the former splendour and cultural value of historic houses in Sopot were launched. The authorities of the city, realizing how valuable the historical image of the city-resort is, started to favour the policy facilitating the process of revitalization. Since 1998 local programmes have been functioning. Their aim is to financially help the housing communities through financing modernization of façades and roofs of historic tenement houses. Since 2005 Sopot, together with the Municipal Conservation Officer have been running the programme aimed at saving the dilapidated Sopot verandas.

\section{Sopot verandas}

Wooden verandas are one of the characteristic features of historic architecture in Sopot. Their origin is associated with the Swiss (Alpine) style, which was very fashionable at the turn of the 20th century and quite common in numerous European resorts of the day. Verandas were commonly used in residential buildings and boarding houses. They had a representative function and were also used as summer parlours, where the residents and guests could socialise, have meals and protect themselves from the caprices of summer weather. On hot days, the verandas were usually opened, while on cool ones they were closed by casement windows, installed with the use of special holders or hinges.

The verandas and wooden structures were inseparably associated with the historical architecture of Sopot. The verandas were usually symmetrically arranged on the façades, although it was not a rule and depended on the shape of the entire building. Two most characteristic ways of placing verandas and wooden structures on façades may be distinguished with regard to residential buildings and boarding houses in Sopot.

The first one concerned mainly the boarding houses, located in the seaside area in the lower part of the city. Those were cheap buildings, simple in form, usually with two storeys and a gable roof with a small angle of inclination. In such houses the verandas constituted the main, and often the only decorative element, and were usually placed on the symmetrical axis of the façade. They were usually one- or 
two-storey extensions without cellars, built on a rectangular or, less often, on a polygonal base (foundation wall). It is also possible to find examples of buildings where a veranda was a kind of a bay window suspended over the ground floor on the floor beams protruding from the wall (figure 1).
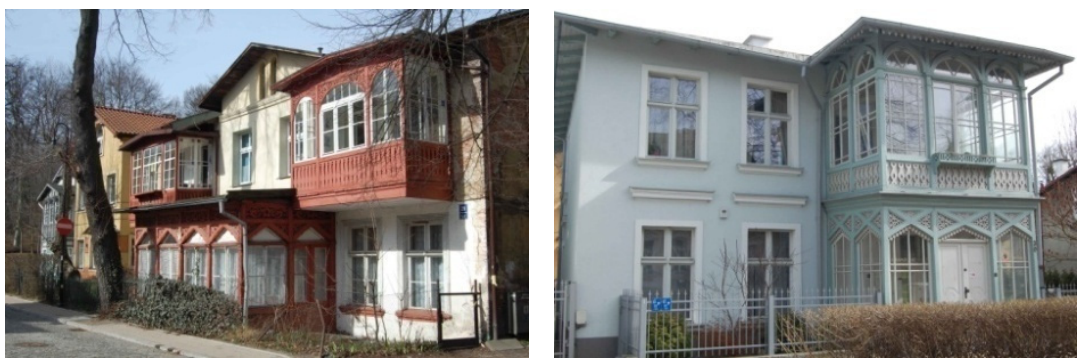

Figure 1: Wooden verandas as a dominant element of the façade composition; verandas in Majkowskiego Street (left) and Haffnera Street (right).

The verandas and wooden structures were placed in a different way on representative residential tenement houses. Those were three-storey or higher buildings with interesting structure and rich in architectonic detail, with sculptural roofs covered with ceramic tiles. The tenement houses represented a combination of various styles (Classicism, Eclecticism, Art Nouveau and even modernism) joined in a free, rather random way, which gave each of the residential districts a diverse and picturesque character. With regard to these buildings, the verandas were only an element supplementing the form and detail, and played the role similar to that of other architectonic elements, such as turrets, balconies, bay windows (built of brick or wood) and dormers. The verandas were not symmetrically placed. Just like the whole structure and the façades of the buildings, they were designed without retaining one symmetrical axis. Also, there was more freedom as far as the shape of the verandas was concerned - they were not constructed following a typical design, which was usual in the case of boarding houses (figure 2).
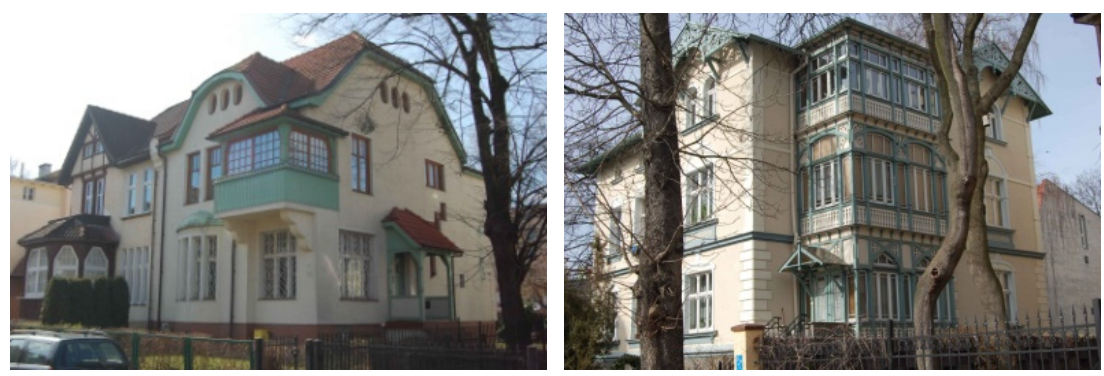

Figure 2: Verandas and wooden structures on the façades of tenement houses; tenement house in Parkowa Street (left) and Mokwy Street (right). 
The common feature of all Sopot verandas was the material - wood. The spandrel-beam construction of verandas was wooden, with decorative boards and windows mounted in the birdsmouths of the spandrel-beam construction. The under-sill spaces were richly decorated with intricately carved rows of wooden boards, inspired by the patterns of Swiss and Tyrolean balustrades. The ornaments on openwork window frames were dominated by symmetrical geometrical or plant motifs. Those openwork forms, resembling lace curtains, were used as the decorative elements for the upper part of the windows. The veranda cornices were finished with profiled boards beams and slats. The wooden architectonic details of individual Sopot verandas did not significantly differ from each other and were based on ready-made patterns elaborated by designers. However, the use of catalogue, repetitive motifs did not negatively affect the quality of the detail. In fact, it was quite the opposite - the lacy patterns and ornaments, precisely cut in wood with a jigsaw, made Sopot verandas even more attractive to look at (figure $3)$.
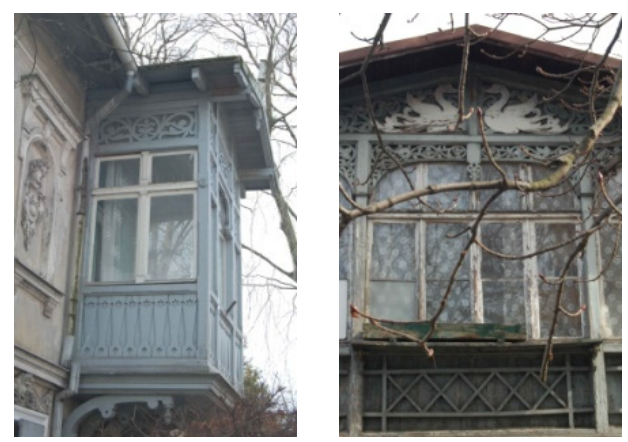

Figure 3: Wooden verandas and their architectural detail; verandas in Mokwy Street (left) and Haffnera Street (right).

\section{Re-use of wooden verandas}

Most of the residential buildings and boarding houses in Sopot, which were constructed at the turn of the 20th century have survived till today, including approximately 300 buildings equipped with verandas. Walking along the streets of Sopot in winter or in spring and looking at historic verandas, we may observe that they are not often used as living areas. Their play the role of storage rooms or ancillary rooms. Furniture covered with dust and other items stored in the verandas can be seen by passers-by through glazed walls, and are not an attractive sight. It is a serious problem concerning the image of this historic resort. On the other hand, it is difficult to feel surprised at this state of affairs, since the verandas, previously used only seasonally, do not meet today's requirements for living areas. In this situation, it is not enough to perform redecoration, renovation or reconstruction of historic verandas without increasing their utility value.

Partial reimbursement by the city of costs connected with renovation of the verandas, definitely constitutes an incentive for their owners to commence 
renovation works. An additional and probably bigger incentive would be an extra economic benefit gained in the form of a full value living space obtained as a result of the veranda modernization. Taking into account the fact that the prices of real property in Sopot (especially in its historic districts) are among the highest in Poland, modernization combined with increasing the utility value of a historic veranda would positively contribute to both the standard and the real value of the whole flat or house.

To summarise the above-mentioned considerations, it may be stated that preparing systemic design solutions and modernization methods is becoming extremely important. Such solutions would improve the landscape and cultural value of the city, and would constitute a tangible value for housing communities, as well as for the owners of houses and flats - therefore, for all the citizens of Sopot.

Sopot wooden verandas were an extremely picturesque element of the city's landscape. Unfortunately, the wood used in their construction was not sufficiently weatherproof to survive without any proper maintenance for almost half a century (from the end of World War II until the 1990s), taking into consideration the adverse influence of the climate in the autumn-winter period.

The degree of damage suffered by the historic wooden verandas was not uniform. There were the cases where only the window woodwork, parts of the ornamental wall lining, or parts of the spandrel-beam construction had to be replaced. There were also the cases where the construction of a veranda was damaged to the degree which excluded any possibility of renovation or modernization, and where the only solution was a total reconstruction. In some cases the damage or wear of the material took place during the post-war years and the verandas did not survive until the time when Poland regained its sovereignty. In the post-war period, the dilapidated verandas were demolished and substituted by brick extensions, deprived of any aesthetic values. In the latter case, the only possible action would be so-called "conservation creation" [3].

The area of historic Sopot is under the protection of the Municipal Conservation Officer, and some of the most valuable buildings are listed in the Register of Historic Monuments. In the case of historic buildings it is essential to establish precisely (together with the conservation expert acting as a designer) which means and methods should be applied in the course of restoration works. However, even during renovation, modernization or reconstruction of historic objects it is possible to find compromise solutions and, as a result, increase the utility value of the object or its part. The conservation creation obviously makes it possible to have more freedom in planning the scope of modernization and in the application of solutions concerning the architectonic design, construction and installations. Thus, the creation allows, to a greater extent, for obtaining higher utility value.

\section{Design issues}

The issues have been discussed from an architect's point of view, based on his own experience gained during the modernization of a historic residential building 
at Lipowa Street in Sopot. It is a two-storey building, with partly usable attic and full basement, constructed in 1894. The building has not been entered into the register of historic monuments; it is merely located within the conservation area, which gave certain freedom of action to the architects. Design solutions were agreed upon with the local Conservation Officer at the stage of conceptual and construction design.

In the building, the front façade and entrance (side) façade survived in their original form, whereas the other two façades were significantly degraded. In the back façade, the window arrangement was repeatedly and randomly changed, while at the side façade, a single-storey lean-to was built on original basement walls. The remaining basement walls and the arrangement of window openings in the side façade implied the existence of a demolished part of the building, whose size was that of a veranda. Unfortunately, no archival materials or pictures which would allow us to learn about the original arrangement of the side façade have survived. Parts of some floor plans is everything that has remained from the archival design documentation dating back to the end of the 19th century, and their analysis has confirmed the initial conclusions.

\subsection{Composition, architectural form and detail}

At the beginning of the modernization, there was a plan to demolish the brick leanto, which does not have any aesthetic value. The composition of the side façade was random and required some design works. The proportions of the whole building were also irregular, hence a decision was made to apply $3 \mathrm{D}$ form in the side façade. It would be justified to recreate the historic veranda, yet as it was impossible without any iconographic materials, the only remaining solution was a historicizing stylization, a creation (figure 4).
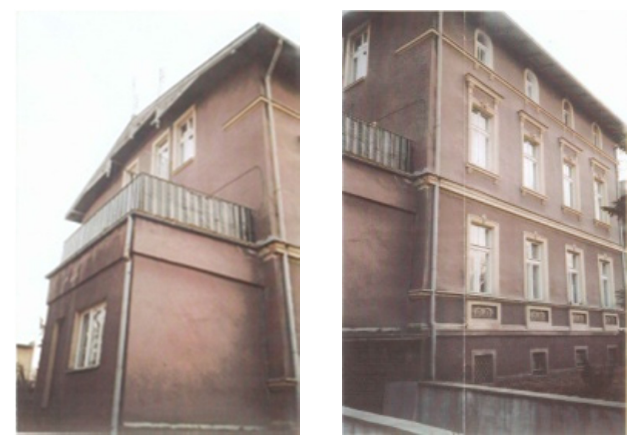

Figure 4: Façades before modernization with the brick lean-to.

The pre-design works started with the analysis of historic tenement houses and verandas characteristic for Sopot, their architectonic form, proportions, façade division and applied details. The analyses were supplemented with examination of the composition and proportions of the side façade of the building in question, as well as of forms and materials, which it would be possible to use, and which would 
be appropriate with regard to architectural and urban context of the city. As a result, a two-storey wooden veranda was designed, whose scale and articulation of divisions was characteristic for historic verandas. A terrace with a wooden balustrade, functionally connected with the flat in the attic, was designed for the top of the veranda. The conservation creation should not copy historic patterns, hence the façades of the veranda had a shape characteristic for Sopot verandas, yet without copying the historic forms. Similarly, the applied architectonic detail was significantly simplified in comparison with the historic originals. It should be remembered that the above considerations on form, composition and detail may be used in creation, not in reconstruction (figure 5).
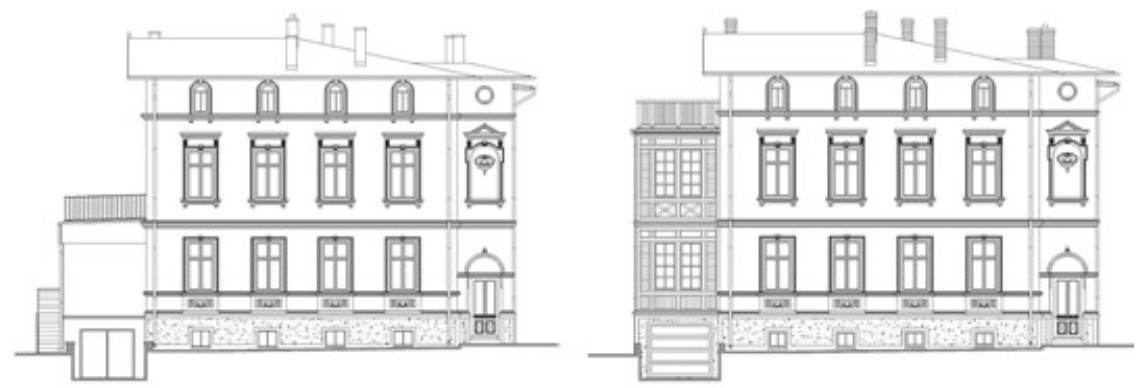

Figure 5: Front façade before modernization (left) and after modernization (right).

\subsection{Construction, fire and thermal protection, acoustics}

Rectangular or polygonal historic verandas had a wooden construction and were connected with wooden floors of the buildings. Their spandrel-beam construction consisted of square or rectangular pinewood squared timber (mainly of 12-14 cm cross section) connected by tenons or wooden pins. Wooden floors were laid on wooden beams. The floor beams were not covered from the bottom or they were finished only with plywood headlining. Nowadays, such arrangement of floor layers does not meet the requirements of fire protection, acoustics and thermal insulation. Similarly, the external wooden walls without thermal insulation or single-pane windows do not fulfil the requirements of thermal insulation and energy efficiency. In the case described here, it was decided to use a modern design solution, i.e. a steel frame structure with wet cast reinforced concrete floors.

Acoustic insulation, which prevents sound spreading, was applied in the mezzanine floor. Wooden, self-supporting external walls of the veranda were designed as shell walls with the use of spandrel-beam construction. The thermal insulation was designed from the interior side, choosing its thickness so as to obtain the "U" heat transfer coefficient, which would comply with the norms currently binding in Poland. Their ventilation was ensured (between the thermal insulation and external boarding), to prevent out-dropping inside the partition. The interior was finished with plaster boards (figure 6). 

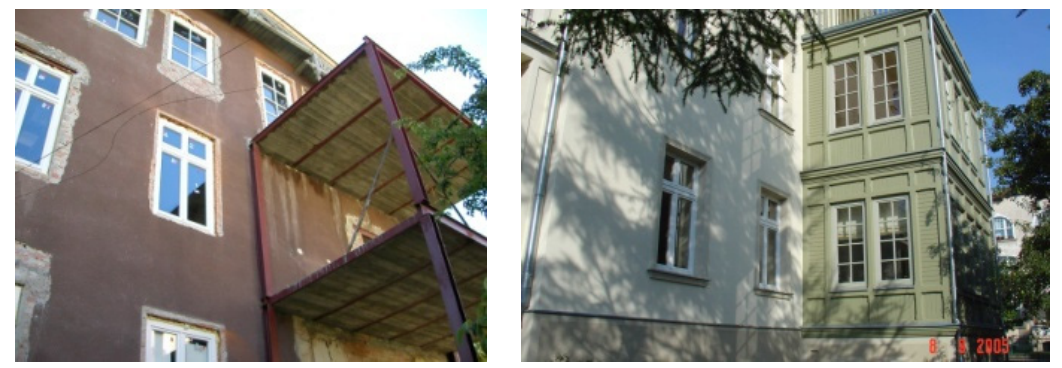

Figure 6: Veranda under construction (left) and veranda at present (right).

The obtained results allowed for providing proper comfort for users in line with current requirements, ensured fire protection of walls and floors and decreased energy consumption, while maintaining the historicizing detail and form integrated into the architectonic context, as well as into the historic and cultural image of the city (figure 7).
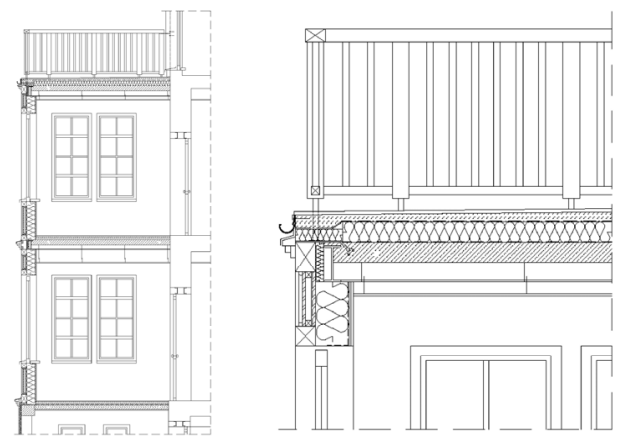

Figure 7: Veranda section (left) and detail of the terrace on the top (right).

The described design works may be used, to a certain degree, as systemic solutions. In case of reconstruction, no free creation of architectonic form is possible, and there is no possibility to alter the construction arrangement, either. However, the remaining actions, which ensure that the current requirements are fulfilled, and that the re-use of historical verandas complies with the rules of sustainable development may constitute a recommended approach in modernization of historic verandas.

\section{Summary}

The example of Sopot verandas shows that re-use of historic buildings or their parts may bring substantial benefits not only to the historic and cultural image of the city, but also to the owners and users of historic buildings. Increasing the utility value and adjusting the degraded historic buildings to the requirements of their 
contemporary users may be obtained by way of modernization works. The means and methods used in modernization sometimes have to satisfy conflicting requirements, i.e. the increase of utility value and preservation of historical values. One universal modernization method does not exist and every case must be approached individually. It is particularly important in the case of historicizing creation, which allows for some freedom in making design decisions. Moderation in design and respect for historic architecture should bring the best results in the form of harmonious coexistence of original historic elements and those designed nowadays.

\section{References}

[1] Pokrzywnicka K., Juchnevic K., Friendly innovative health resort - Case study, International Scientific Conference Urban Landscape Renewal-ULAR 6, pp. 351-356, 2012.

[2] Petrus K., Post-war reconstruction and adaptation of tenement houses ruined in World War II, Technical Transactions-Architecture, Issue 13, Year 106. pp. 133-156, 2009.

[3] Tajchman J., Podstawowe zagadnienia metody konserwacji i restauracji dziedzictwa architektonicznego w zakresie zabytkowych budowli. Współczesne problemy teorii konserwatorskiej w Polsce, ed. Szmygin B., ICOMOS: Warszawa and Lublin, pp. 155-167, 2008. 